between $\mathrm{NO}_{2}$ and either the solvent or impurities contained therein.

Radicals described as $\mathrm{NH}_{3}-\mathrm{C}_{2} \mathrm{H}_{2}{ }^{+}$and allyl alcohol diradicals are without doubt other species than these, and the presence of a hyperfine splitting from ${ }^{129} \mathrm{Xe}$ in irradiated $\mathrm{CF}_{\star}$ is certainly surprising !

It would scarcely seem necessary to illustrato spectra for polyerystalline diphenylpicrylhydrazyl, or indeed for aqueous $\mathrm{Mn}^{2+}$, but to find both these spectra referenced as "unpublished results" is quite astonishing.

M. C. R. Symons

\section{SENSE OF PERSPECTIVE}

\section{The Graphic Work of M. C. Escher}

Pp. 24+69 plates. (London: Oldbourno Book Co., Ltd., 1967.) 42s. net.

"AlтнобGн I am absolutely innocent of training or knowledge in the exact sciences," Escher writes in the introduction to this book, "I often seem to have more in common with mathematicians than with my fellow artists." In the principles of symmetry, inversion and topology that so dominate his work, Escher shares a common interest, superficially at least, with chemists and crystallographers as well as with mathematicians. Yet scientists no less than others will wonder whether the intriguing visual paradoxes that Escher conjures forth from the formal qualities of line and plane in fact transcend their own virtuosity.

Escher's impossible buildings, achieved by subtle perversions of the rules of perspective, are among the best known of his works. A genre that he has made his own is the exact filling of a space with two or more sets of discrete objects which interlack perfectly with each other. Another common theme is the blending into one composition of two mutually incompatible situations. "Day and Night", for example, shows on the left hand black birds flying over a daytime landscape and on the right hand white birds flying over the mirror-image landscape under cover of darkness; the centre of the picture, with romarkable dexterity, merges the two flocks of birds into each other and into the contraposed landscapes.

But after the tricks and the trompe-l'oeil, what remains? Is there a serious substance in these drawings, or are they to be dismissed as amusing exercises in technique, no more significant than the visual illusions beloved of psychologists? Escher himself points out that two of his motifs were taken from an article in tho British Journal of Psychology, and the bizarre naivety of the grinning fishes and dwarflike men that populate many of the drawings cannot but confirm the impression of frivolity.

Beneath the pyrotechnics there is, perhaps, a profounder purpose. Lévi-Strauss, possibly with tongue untypically in cheek, has remarked of abstract art that it is concerned with style, not content, and that an abstract work shows the mannor in which the artist would execute his pictures if he were by chance to paint any. In a similar way it seems that Escher is preoccupied with the conventions of ropresenting three dimensions in two, and that his pictures are inquiries into the logic of perspective and the assumptions made both by the hand of the artist and the eyo of the beholder. Escher says in his notes on the pictures, "The two dimensional is every bit as fictitious as the four dimensional, for nothing is flat". His work is an explora. tion of the absurdities that spring from this fiction and, it may seem, is a statement of the problems to be overcome before he could himself portray the world as he sees it. The plates grouped under the heading "Conflict between the Flat and the Spatial" are a remarkable and not merely entertaining exposition of these absurdities.

At two guineas this book is moderately priced, and to those who decline to accept it as art, its illusions should give a good run for their monoy.

N. M. L. WADE

\section{OBITUARIES}

\author{
Professor J. L. B. Smith
}

Professor J. L. B. Smith, the South African ichthyologist, died at his home in Grahamstown on January 7 , 1968. At the time of his death he held the research professorship of ichthyology at Rhodes University.

Professor Smith's name will always be associated with the discovery and description of tho oxtant coelacanth crossopterygian, Latimeria chalumnae, captured in December 1938 near East London. The circumstances surrounding this event, and the subsequent fourteen-yearlong campaign to obtain a second specimen, were vividly described by Smith in his book Old Fourlegs (1956). This account revealed (as its author realized) a great deal of the man, and rarely can have beon equalled as a frank character-study of a determined and dedicated man.

Born at Graaff Reinet in 1897, Professor Smith was educated at a number of schools including "Bishops" College, and the Victoria College, Stellenbosch. It was at Stellenbosch that his interest in chemistry was first aroused, and it was as a chemist that he joined Rhodes University College, Grahamstown, as a lecturer in 1923, after obtaining a Ph.D at Cambridge. During the First World War, Smith served with the South African Forees in East Africa.

From 1923 until 1947 Smith lectured in chemistry at Rhodes, producing soveral papors and three textbooks on chemical subjects. His spare time, however, was largely devoted to studying fishes. It was during this period that, in addition to his work on the anatomy of Latimeria, he laid the foundations for his most widely known work, The Sea Fishes of Southern Africa. In 1947, the South African Council for Scientific and Industrial Research awarded Smith a research fellowship which enabled him to resign his post in the chemistry department and thereby dovote his full energios to ichthyology.

Smith's interest in fishes stemmed from an early contact with them as a sea-angler. This introduction left its mark on all his subsequent work which, as far as possible, he based on personal acquaintance with the fishes in the field. His love and enthusiasm for angling, and his appreciation of the angler's problems, led Smith into wide and profitable contact with the public. There is probably no other ichthyologist who can claim to have had queues forming outside bookshops on the day his regional monograph was published. Yet this was the reception that Smith's great work The Sea Fishes of Southern Africa received in 1949.

Essentially synoptic in its treatment, Sea Fishes was followed by a series of family and generic revisions of species from South African waters and the wostern Indian Ocean, as well as numerous shorter papers dealing with new taxa. In 1963, Smith and his wife published another important regional synopsis, Fishes of the Seychelles, covering an area the marine fauna of which had received scant attention since the mid-nineteenth century. In all, Smith produced more than two hundred papers and articles on ichthyological subjects.

Although there is a long history of ichthyological research in South Africa, Smith's investigations have undoubtedly added more to our knowledge of the fishes from this vast marine area than have those of any of his predecessors. Smith's work was essentially pioneering, and his attitude that of a field-worker faced with the task of mapping a complex and rich fauna still imperfectly known. At times this brought him into conflict with European and American workcrs, particularly on questions of nomenclature. The momentary heat-haze generated by these differences cannot, howover, obscuro the fact that J. L. B. Smith's drive and dedication re. sulted in a very significant contribution to ichthyology. 
Professor Smith is survived by his wife, Margaret M. Smith, who was his close collaborator in the field and laboratory, and who was responsible for most of the illustrations in his many papers. $\quad$ P. H. Greenwoon

\section{Professor George Macdonald}

Professor George Macdonald, one of the most domi. nant figures in the world of tropical medicine for twenty years, died on December 10, 1967, in University College Hospital.

The son of John Smyth Macdonald, FRS, Professor of Physiology at Sheffield and later at Liverpool, George Macdonald graduated M.B., Ch.B. at Liverpool University in 1924 at the age of 21 and took his D.T.M. in the same year. In 1925 he went as a research assistant to the Sir Alfred Jones Laboratory at Freetown, Sierra Leone, and in 1926 he published the first of his many papers on malaria. After graduating M.D. Liverpool and taking the London D.P.F. in 1932, he spent seven years in India and Ceylon and returned to England as assistant director of the Ross Institute in 1939. He joined the Royal Army Medical Corps and after a short period as D.A.D.H. Salisbury Plain Area he was appointed to form and command the first Malaria Field Laboratory. This unit had an adventurous career in Greece and Crete.

In 1942 he was appointed consultant malariologist to the Middle East Forces, and his advice saved the Eighth Army from burdening itself with hundreds of tons of antimalarial equipment during its advance to Tripoli. In 1947 he became the first professor of tropical hygiene at the London School of Hygiene and Tropical Medicine, and director of the Ross Institute.

He was a pioneer throughout his life. In Ceylon he devised an automatically flushing siphon for antimalarial drainage, the appearance of which was followed by a spate of "new and improved models". In London, when he turned his mind to the quantitative epidemiology of malaria, the answers to entomological questions he posed were not available; his reaction was to set up the Ross Institute's own entomological unit, now an established leader in research on anophelines. In 1957 he published his collected malariological work in The Epidemiology and Control of Malaria (O.U.P.), a book which mathematicians and others could read with equal pleasure and profit. He was a member of the World Health Organization's Expert Committee on Malaria from its inception, and (theoretical though his work seemed to some people) on several occasions he reasoned out epidemiological methods with strictly practical field application.

The epidemiology of malaria, an asexual infection in man, involved relatively simple mathematical calculations which were soluble with hand calculators-and with help from professional statisticians which he freely acknowledged. When he turned his mind to helminthic and therefore sexual infections the aid of a computer was needed. Characteristically, he learned to produce his own programmes and in due course published a mathematical model for the epidemiology of schistosomiasis. This too has thoroughly practical implications, not least in initiating healthy controversy in a new subject.

As a teacher Macdonald tended to lecture above cloud level. But his formidable brainpower and concentration were freely available to anyone who went to his office, and he solved the problems of hundreds of callers, correspondents and committees. He met the knowledge of impending death with great mental and physical courage, carrying on creative work and inspiring others to the last possible moment.

He was made C.M.G. in 1953, and received the Darling Foundation Award in 1954 and the Bernhard Nocht Medal in 1963. He was president of the Royal Society of Tropical Medicine and Hygiene in 1965-67.

B. B. WADDY

\section{Professor Frank Raw}

Professor Frank Raw died suddenly, in his fortyseventh year, on October 1, 1967, in Brisbane. He had been professor of entomology in the University of Queensland, Australia, for six months.

Graduating from Queen Mary College, University of London, in 1942, Raw began research in Cambridge under Salt and Hollick with the war-time team studying wireworms in agriculture, work which included pioneer studies of the gencral arthropod fauna of pasture and arable soils - a subject that remained Raw's chief interest. After two years he became an advisory entomologist at the Research Station, Long Ashton, later transferring to the National Agricultural Advisory Service, where he continued his work on insects of pasture soils with a broad ecological study of the garden chafer beetle.

In 1948 Raw joined the staff of Rothamsted Experimental Station, and remained there until 1967, specializing in the agricultural aspects of soil zoology. During this period, however, he spent two years at the West African Cocoa Research Station, in what was then the Gold Coast, studying the control of cacao capsids with chlorinated hydrocarbon insecticides; this early work has since led to much improvement in cacao growing.

Raw's work very successfully combined fundamental and practical approaches, and his zoological studies were always related to the effects of soil animals on the yield of crops, an aspect of research in agricultural entomology still much neglected. He continued to study the biology of wireworms at Rothamsted and he made experiments in collaboration with the insecticides department on the chemical control of these pests especially with chlorinated hydrocarbon seed-dressings; this notably contributed to current methods of control. Nevertheless, he also studied side-effects both of chlorinated hydrocarbon and of organophosphorus insecticides on the invertebrate animals in the soil. By improving methods of extracting these animals he revealed the unexpected abundance of Protura, a group that had before been considered as being sparse.

Raw's work on earthworms is well known and his technique of using formalin for sampling populations of worms is now a standard method. He showed, especially in apple orchards, how weather and chemical sprays affected the abundance and activity of worms, how these changes affected the burial of fallen leaves and the incorporation of leaves into the soil as nutrients for the trees; this work also raised problems of the removal from orchards of the spores of the fungus causing apple scab when worms buried dead leaves.

In his studies of the wheat-bulb fly, cut short at a most promising stage, he related the population dynamics of the insect to damage done to wheat crops. He studied the effects of fallow, both locally and nationally, of seedrates, tilth, fertilizer treatment and different varieties of wheat on the response of the crop to attack by this pest. Raw was more aware than most workers that the abundance of a pest is only one of the many factors to be considered when studying loss of yield on crops caused by insect attack and that various ecological interactions between crop, pests and associated organisms are important in agricultural entomology. He had a special ability, not common among research entomologists, to see pests in a broad agricultural context. This wide approach is evident in Raw's publications and especially in his joint editing of the recent treatise, Soil Biology.

Raw was, for long, an active officer of the Association of Applied Biologists and for the past seven years its esteemed treasurer.

It was expected that he would influence the subject of agricultural entomology greatly in his new appoint. ment, for his clarity of thought and of exposition was exceptional.
C. G. JOHNSON 